Bond University

Research Repository

\title{
Persuasion in negotiation and mediation
}

Wade, John

Published in:

ADR Bulletin

Link to output in Bond University research repository.

Recommended citation(APA):

Wade, J. (2007). Persuasion in negotiation and mediation. ADR Bulletin, 10(1), 1-5.

\section{General rights}

Copyright and moral rights for the publications made accessible in the public portal are retained by the authors and/or other copyright owners and it is a condition of accessing publications that users recognise and abide by the legal requirements associated with these rights.

For more information, or if you believe that this document breaches copyright, please contact the Bond University research repository coordinator. 
Bond University ePublications@bond

Law Faculty Publications

Faculty of Law

$10-1-2008$

\section{Persuasion in negotiation and mediation}

John Wade

Bond University, john_wade@bond.edu.au

Follow this and additional works at: http://epublications.bond.edu.au/law_pubs

Part of the Dispute Resolution and Arbitration Commons

\section{Recommended Citation}

John Wade. (2008) "Persuasion in negotiation and mediation" ,, .

http://epublications.bond.edu.au/law_pubs/237

This Journal Article is brought to you by the Faculty of Law at ePublications@bond. It has been accepted for inclusion in Law Faculty Publications by an authorized administrator of ePublications@bond. For more information, please contact Bond University's Repository Coordinator. 


\title{
Persuasion in Negotiation and Mediation
}

\author{
John Wade \\ Professor \\ Faculty of Law \\ Bond University
}

\section{Summary}

This article endeavours to provide a framework for common patterns of behaviour and persuasion observed anecdotally in high conflict negotiations in civil and family disputes, often including legal representatives. It sets out:

- Some introductory boundaries to the topic of "persuasion"

- A composite model of a persuasive lawyer - negotiator

- Basic negotiation patterns

- The task of creating doubt about rights, goals and power

- Cialdini's sales levers

- Persuasion and pause

- A glimpse at deception of others during negotiation

- A glimpse at deception of self and "decision traps".

- Persuasion via "intangibles" - procedural skill and emotional awareness.

\section{Introductory Boundaries to the Topic of "Persuasion"}

Here are a few initial reflections on some challenges and nuances of studying persuasion. Each is subject to considerable anecdotal and scholarly study.

A working description of "persuasion" is - an attempt to change the beliefs, emotions and behaviours (including language) of others. Of course, persuasion can be achieved by advertisements, biographies, torture, spanking, warfare, dreams, drugs, flattery and counselling.

(1) The ubiquitous complexity, and sometimes mystery, of human behaviour, beliefs and emotions means that any insights and frameworks are fragile and tentative. Nevertheless, a conscious framework is more helpful to planning and correction than a subconscious framework.

(2) Attempted persuasive behaviours will have varying degrees of "success" on different targets. A zealot conflict-junkie with "nothing to lose" will not be persuaded by the usual, or perhaps any, skilled persuasive routines.

(3) The above comment applies especially to attempted communication and persuasion across substantially different cultures. Persuasive methods chosen, and degrees of effectiveness, vary dramatically from culture to culture. ${ }^{1}$

(4) All human beings are "trapped" to different degrees, by beliefs, emotions and behaviours which are outside systems of rational analysis (irrational, arational or

See R. Lewicki et al, Negotiation (2006), Ch. 16. 
beyond rationality $)^{2}$ It is a particular challenge in negotiation to diagnose "rationally" whether perceived own or other irrationality is feigned (good copbad cop), temporary, "real", or cultural; and what array of persuasive strategies might work against irrationality. For example, a standard strategy is to "bring a wise friend" who is then subject to normal persuasion techniques.

(5) Persuasion is attempted and will have varying degrees of "success" with a range of people involved in any negotiation or mediation including:

(a) - within a team of hawks, doves and moderates who are either "present" or in the shadows (sometimes known as "tribes", cheer squads or constituents) ${ }^{3}$

(b) - between teams of hawks, doves and moderates, who are again either present or elsewhere such as shareholders, bosses, patriarchs or new spouses.

(c) - with self! The negotiation environment is also key for persuading or rationalising to self that decision made is OK, satisfactory, wise or even excellent. "Am I missing something here"; "This is what I am thinking am I wrong?" "Why should I move? Can you help me?"

(d) - with a mediator, especially a mediator of the "evaluative" type. ${ }^{4}$ If an evaluative mediator can be swayed or persuaded, (s)he will then pass on the persuasion via practised mediator persuasion techniques.

(6) Persuasion is attempted via a variety of venues and forms - your place, my place, neutral place, open or closed to publicity, secretly or publicly, by conversation, letters, phone, email, single meeting, multiple meetings, long or short, with or without extensive preparation, years before, or the day before a court determination, with or without the assistance of a mediator or chairperson. Persuasive techniques chosen will usually differ according to these variables.

(7) A variety of different, though overlapping, persuasive techniques are usually attempted at the different stages of any negotiation - for example:

- just re-opening communication after "hostilities" or deadlock ${ }^{5}$

- persuading representatives to "come to a table" or exchange correspondence and problem solve

- opening speeches at any meeting, phone call or initial interchange of correspondence

- vigorous interactive debates, tense "doubt-creation" mid-way through any negotiation

- $\quad$ subtle, and non-so-subtle strategies for crossing the last gap at the end of a negotiation when nerves are frayed and anger or despair is again escalating. ${ }^{6}$

2 Hammond et al, Smart Choices (1999); Cordelia Fine, A Mind of Its Own (Australia: Allen \& Unwin, 2005).

3 See J.H. Wade, "Bargaining in the Shadow of the Tribe" (2003) 15 Bond Law Review 115; also in A. Schneider and C. Honeyman, The Negotiator's Fieldbook (ABA, 2005) 475.

$4 \quad$ See L. Boulle, Mediation: Principles, Process, Practice (2ed 2005)

$5 \quad$ Pruitt and Kim, Social Conflict (2003); J.H. Wade, "Dobermans and Diplomats: 17 Strategies for Reopening Hopelessly Deadlocked Negotiations" in (2006) Bond University Dispute Resolution Newsletter http://www.bond.edu.au/study-areas/law/publications/drn/index_drn.html. 
(8) Many activities could be classified as "pre-persuasion"; or "setting the scene for persuasion"; or "merely emotional or procedural pre-conditions" to persuasion. For example, preparatory documents, exchanged summaries, graphs, charts, preparatory phone calls, politeness or not, food or not, gracious hosts or not, bring a supporter or not etc might be classified as "pre-persuasion". However, the writer disagrees with such artificial boundaries and is convinced that potential "persuasion" and "changed or confirmed perceptions" are occurring with every casual or formal encounter between negotiators and their constituents.

(9) Negotiators use different, though again, overlapping persuasion techniques not only to reach a "settlement", but also one that is durable. ${ }^{7}$

(10) A persuader can be motivated predominantly by perceived or actual self-interest; (eg "I want to make a profit"; "I will not be beaten by you") or predominantly by perceived or actual interests in others; ("This early settlement/medicine/exercise will assist you to recover"; "this offer is so generous because I genuinely want to assist you") or a combination of both selfinterest and interest in others.

(11) "The right offer at the wrong time is the wrong offer". An entirely persuasive message sent will not be received, unless and until the other party acquires the ears to hear. ${ }^{8}$

\section{A Composite Model of a Persuasive Lawyer-Negotiator}

I will begin with a description of the features of several lawyers whom the writer has anecdotally observed to be repetitively "persuasive" and "successful" in negotiations within Australia. (NB They too have a percentage of perceived "failures"). Each feature is worthy of several Ph.D. theses. Each feature is also supported by a host of more systematic studies in psychology, communication and negotiation, though these model lawyers probably have read only few if any of such studies.

The broad sweep of these features indicates the complexity of a notion such as "persuasion".

These "persuasive" and highly competent negotiators exhibit the following features:

- A sustained reputation for the features which follow!

- Attentive listening and summarising skills

- Detailed preparation and intra-team training

- Gracious hosts

- Articulated awareness and flexibility about procedural options during negotiation

- Self-deprecating humour (eg "I became a lawyer because I cannot add"; "I forgot to take my pills again this morning")

- A balance of focus on big goals (the forest) and fine detail (the trees)

- Stunning memories for detail and instant ability to produce copies of key documents

6 eg J.H. Wade "The Last Gap in Negotiations: Why it is Important? How it Can be Crossed?" (1995) 6 Aust D R Journal 92; also Schneider and Honeyman, note 3, 467.

7 See J.H. Wade \& C. Honeyman, "A Lasting Agreement" in Schneider and Honeyman, note 3, 485.

$8 \quad$ I.W. Zartman, "Timing and Ripeness", ch 17 of Schneider and Honeyman, note 3. 
- Polite creation of doubt by words, diagrams or raised eyebrows

- Patience and persistence

- Well timed and worded questions

- A range of pithy and memorable analogies, stories and expressions

- Scrupulous "honesty" (though not necessarily "full" disclosure)

- Articulated awareness of the fallibility of human decision-making ("Am I missing something..."? $)^{9}$

- Repetitive and frank re-evaluation of fallback options

More systematic researchers would take each of these "features", design control groups and attempt to measure cause, effect, or correlation between:

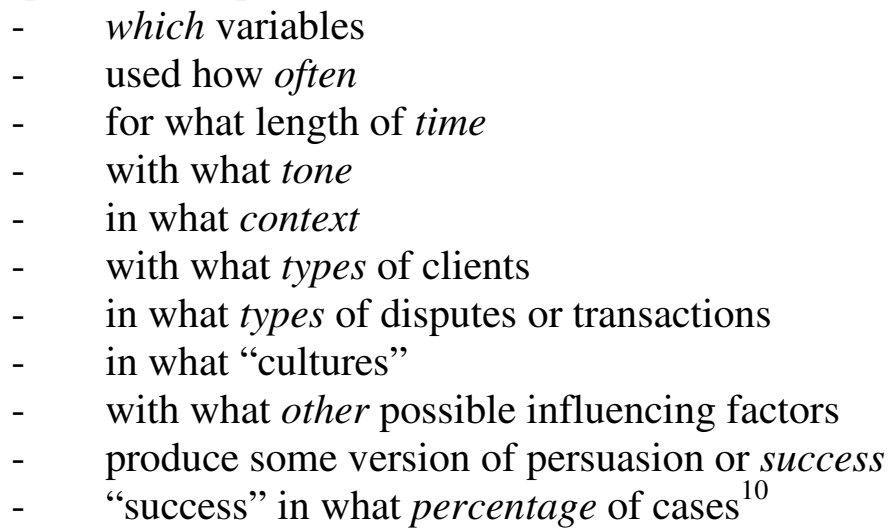

Various commentators in the fields of dispute resolution and of law have pleaded for a century (usually in vain) for respectful alliances between story-teller, systematisers and statisticians - or between practitioner anecdotes, abstract theories, and scientific research. ${ }^{11}$ Each isolated culture has much to offer the other, as medical practicetheory enmeshment often demonstrates.

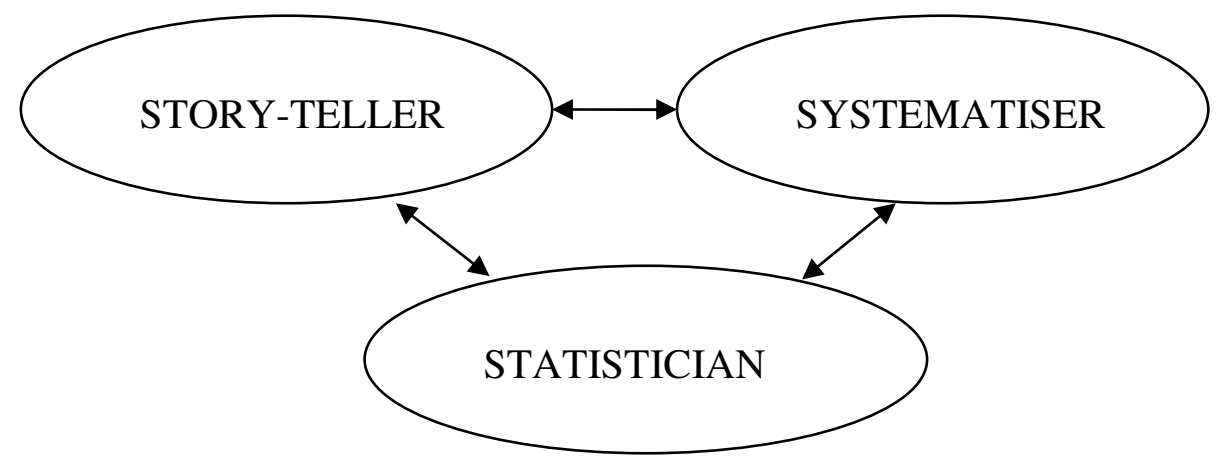

9 Hammond et al, Smart Choices (1999) Cordelia Fine, A Mind of Its Own (2005); R. Lewicki et al note 1.

10 See D. Druckman, Doing Research - Methods of Inquiry for Conflict Analysis (2005).

11 See Druckman note 10, and especially the 2001 classic by C. Honeyman, B. McAdoo and N. Welsh, "Here There be Monsters: At the End of the Map of Conflict Resolution" www.convenor,com/madison/monsters.htm (discusses the theory/practice divide). See also the interesting encounters between practitioners, theorists and researchers ("pracademics") in A.K. Schneider and C. Honeyman, The Negotiator's Fieldbook (Washington: ABA, 2006). 
This paper will now address in more detail just one of these model behaviours, namely "polite creation of doubt by words, diagrams or raised eyebrows".

\section{Basic Negotiation Patterns}

There are many excellent books written about negotiation and persuasion in negotiation. $^{12}$

To repeat - a working description of "negotiation" is an interactive attempt to persuade or influence others to change their beliefs, emotions and ultimately behaviours.

A normal pattern of negotiation is that each team sooner or later sets forth their "position" or preferred solution to the dispute. Even if each negotiation team begins diplomatically with general goals, these eventually evolve into more specific solutions. For example:

\begin{tabular}{|c|c|}
\hline Party wants: & Counterpart wants: \\
\hline - $\$ 10$ million & $\longleftrightarrow$ To pay $\$ 2$ million \\
\hline - An apology & $\longleftrightarrow \quad$ No apology \\
\hline - Suspension from a profession & $\longleftrightarrow$ No suspension \\
\hline - Access to all financial records & $\longleftrightarrow$ No access \\
\hline - Refugee status & $\longleftrightarrow$ Illegal immigrant status \\
\hline - Exclusive use of Jerusalem & Exclusive use of Jerusalem \\
\hline - Large distribution of profits & $\longleftrightarrow$ Small distribution of profits \\
\hline - Promotion & $\longleftrightarrow$ No promotion \\
\hline - Logging of old forest & $\longleftrightarrow$ No logging of old forest \\
\hline $\begin{array}{l}\text { - } 260 \text { overnights with children } \\
\text { etc. }\end{array}$ & $\longleftrightarrow \begin{array}{l}\text { Other to have only } 108 \text { overnights } \\
\text { with children }\end{array}$ \\
\hline
\end{tabular}

Of course, all the above illustrations are of single issue negotiation. It is more common for negotiation to have several inter-related issues being discussed as possible "packages". For example:

12 R Lewicki et al, Negotiation (2005); G R Shell Bargaining for Advantage (1999); R Korobkin, Negotiation - Theory and Strategy (2002); R Fisher and W Ury, Getting to Yes (1991); W Ury Getting Past No (1991); Schneider and Honeyman at note 3. 


\begin{tabular}{|c|c|}
\hline Party (Owner) wants: & Counterpart (Builder) wants: \\
\hline $\begin{array}{l}\text { 1. Damages of } \$ 500,000 \text { for } \\
\text { late construction } \\
\text { PLUS.......... }\end{array}$ & $\begin{array}{l}1 . \quad \text { To pay zero damages due } \\
\text { to contributory negligence } \\
\text { PLUS.......... }\end{array}$ \\
\hline $\begin{array}{l}2 . \quad \text { To pay zero to builder on } \longrightarrow \\
\text { last instalment } \\
\text { PLUS.......... }\end{array}$ & $\begin{array}{l}\text { 2. Cross claim of } \$ 220,000 \\
\text { for last contractual instalment } \\
\text { PLUS......... }\end{array}$ \\
\hline $\begin{array}{l}3 . \quad \text { Return of missing } \\
\text { machinery } \\
\text { PLUS }\end{array}$ & $\begin{array}{l}3 . \quad \text { Denial that machinery was } \\
\text { taken } \\
\text { PLUS }\end{array}$ \\
\hline $\begin{array}{l}4 . \quad \text { No apology } \\
\text { PLUS.......... }\end{array}$ & $\begin{array}{l}\text { 4. Public apology for } \\
\text { defamatory comments about } \\
\text { quality of work } \\
\text { PLUS........... }\end{array}$ \\
\hline $\begin{array}{l}\text { 5. Arbitration clause for } \\
\text { future disputes } \\
\text { PLUS........... }\end{array}$ & $\begin{array}{l}5 . \quad \text { Mediation clause for } \\
\text { future disputes } \\
\text { PLUS........... }\end{array}$ \\
\hline $\begin{array}{l}6 . \quad \text { Line of credit restored } \\
\text { PLUS......... }\end{array}$ & $\begin{array}{l}6 . \quad \text { No future credit over } \\
\$ 50,000 \\
\text { PLUS.......... }\end{array}$ \\
\hline $\begin{array}{l}7 . \quad \text { New building manager } \\
\text { employed for future jobs } \\
\text { PLUS.......... }\end{array}$ & $\begin{array}{l}\text { 7. Same building manager } \\
\text { employed for future jobs } \\
\text { PLUS.......... }\end{array}$ \\
\hline
\end{tabular}

\section{Creating Doubt}

Having created a single line or multiple lines of possible solutions, negotiators then attempt to "create doubt" for their counterparts (or fellow team members). "Creating doubt" or "lowering expectations" consists of a series of predictable and sometimes ritualistic behaviours which attempt to persuade other parties that their stated preferred solution is unlikely to be achieved at negotiations or elsewhere.

Again, it must be emphasised that the to and fro delivery of these routine attempts to create doubt take place with many complex variations - who, when, where, aggressively or diplomatically, in whose presence, straight to the point or by nuance, by metaphor or story, with graphs and charts, in writing of one or hundreds of pages, with speeches or chatter, with humour or solemnity, in one or several "languages", once or repetitively over many exchanges, in a sombre or comfortable environment, by letter, phone or email, with total honesty, limited disclosure or degrees of deception, with positive or negative language.

This process of doubt-creation attempts to challenge beliefs, behaviours and emotions which are attached to each parties' preferred solution(s). 


\section{Creating Doubt About Rights, Goals and Power}

Negotiators use "rights, power and goals" talk interchangeably as they attempt to create doubt. These three categories of rights, power and goals overlap. Nevertheless, it is very useful to attempt to categorise key allegedly persuasive propositions - for example, "rights" talk may be more persuasive for lawyers, and "goals" and "risk" talk more persuasive for business people. ${ }^{13}$
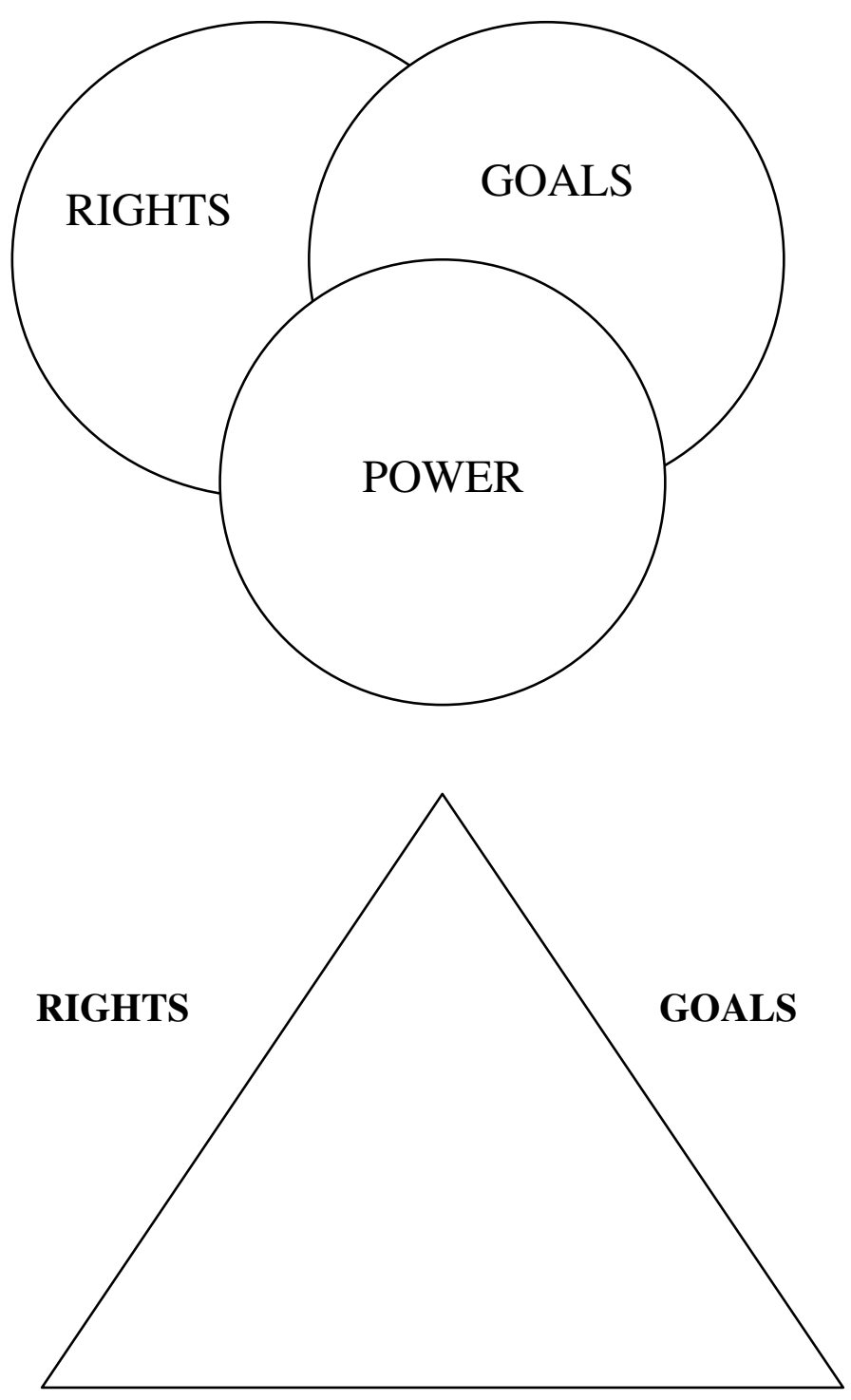

POWER

13 See apparent business disinterest in "rights" - S. MacCauley, "Non-Contractual Relations in Business: A Preliminary Study", (1963) 28 American Sociological Rev. 55; "Elegant Models, Empirical Pictures, the Complexities of Contract" (1977) 11 Law and Society Rev 507. See W.L. Ury, J.M. Brett and S.B. Goldberg, Getting Disputes Resolved (San Francisco: Jossey-Bass, 1993) and A.L. Lytle, J.M. Brett and D.L. Shapiro "The Strategic Use of Interests, Rights and Power to Resolve Disputes" (1999) Negotiation J. 31 for this threefold division. 
All three categories of "doubts talk" can be helpfully considered asking the questions repetitively "If this negotiation does not result in an agreement, what are the best to worst possible/probable outcomes on our current understanding of respective rights, goals and power?" This question is reflected in the well-known acronyms WATNA, BATNA and PATNA (What are the predicted Worst, Best and Probable Alternatives to a Negotiated Agreement?)

\section{(1) "Rights" Talk}

"Rights" can be described as a series of guesses about the range of benefits and losses which may result from legal process and decision-making. As such guesses require considerable legal knowledge and expertise, they should ideally come from the minds and mouths of experienced and reputable lawyers in order to have a degree of persuasiveness. Clients who talk about "justice", "rights", "entitlements" or "fairness" are usually very unpersuasive, even though such concepts may have high personal importance.

"Rights" talk is sometimes called "bargaining in the shadow of the law (and its legal procedures)". ${ }^{14}$

The shadow of the law involves at least the trilogy of doubts of uncertainty, expense and delay. Thus the writer as mediator has supervised numerous mediations where very competent lawyers announce quietly "Can I make it clear that I have advised my client that (s)he will receive between $20-40 \%$ of the estate; incurring legal costs between $\$ 80,000$ and $\$ 120,000$; with delay of between 15-24 months".

Apart from the standard trilogy of risks, there are many other routine doubts attached to litigation which are recited at negotiations, and which quickly overlap with "goals" doubts.

"RIGHTS" TALK is routinely subdivided into the following elements or preconditions to guessing how a decision-maker might behave in the future.

\begin{tabular}{|l|l|}
\hline $\begin{array}{l}\text { 1. FACTS (about intent, history, } \\
\text { causation, future predictions) }\end{array}$ & $\begin{array}{l}\text { "We seem to be working on different facts to } \\
\text { each other..." }\end{array}$ \\
\hline 2. EVIDENCE & $\begin{array}{l}\text { "How will you try to prove that we caused } \\
\text { those losses...?" } \\
\text { "We have copies of three emails..." }\end{array}$ \\
\hline 3. CREDIBILITY & "Who is more likely to be believed?" \\
\hline 4. RULES & $\begin{array}{l}\text { "You are applying the wrong rules." } \\
\text { "That is not how I interpret that case." } \\
\text { "Have you seen the recent cases on...?" }\end{array}$ \\
\hline
\end{tabular}

14 R. Mnookin and L Kornhauser, "Bargaining in the Shadow of the Law: The Case of Divorce" (1979) 88 Yale L J 950. Note the helpful analysis by M. Galanter "A World Without Trials" (2006) J. of Dispute Resolution 7 at 28 where he notes the reverse tendency of mediators "to adjudicate in the shadow of bargains". 


\begin{tabular}{|c|c|}
\hline 5. RULES-INSIDER KNOWLEDGE & $\begin{array}{l}\text { "That is not how the system works here." } \\
\text { "You are a stranger to this jurisdiction..." }\end{array}$ \\
\hline 6. PUBLICITY/REPUTATION & $\begin{array}{l}\text { "The courts are public places, and how will } \\
\text { you feel if this is sensationalised in the } \\
\text { press." } \\
\text { "A judge has a duty to refer any tax evasion, } \\
\text { social security fraud etc." }\end{array}$ \\
\hline 7. DELAY & $\begin{array}{l}\text { "The hearing will not take place for } 1-2 \\
\text { years; and then there is time for judgment } \\
\text { writing and possible appeals." }\end{array}$ \\
\hline 8. COSTS (DIRECT) & $\begin{array}{l}\text { "The predicted range of costs for lawyers and } \\
\text { accountants are..." }\end{array}$ \\
\hline 9. COSTS (INDIRECT) & $\begin{array}{l}\text { "How much time can you afford to be away } \\
\text { from your business/family?" }\end{array}$ \\
\hline 10. STRESS & $\begin{array}{l}\text { "How healthy and strong are you? How will } \\
\text { you manage litigation trauma?" }\end{array}$ \\
\hline $\begin{array}{l}\text { 11. COURT and JUDICIAL } \\
\text { UNPREDICTABILITY and } \\
\text { ERROR PRONENESS }\end{array}$ & $\begin{array}{l}\text { "Litigation is a lottery." } \\
\text { "No-one can predict what a judge will do." } \\
\text { "Outcomes will turn on unpredictable events } \\
\text { like an absent witness; a replacement judge; a } \\
\text { judicial hobby horse." }\end{array}$ \\
\hline 12. JUDICIAL IGNORANCE & $\begin{array}{l}\text { "A judge cannot understand the complexities } \\
\text { of your life/business/culture." } \\
\text { "A judge will make a decision, based on an } \\
\text { unpredictable reconstruction of facts." }\end{array}$ \\
\hline 13. LOSS OF CONTROL & $\begin{array}{l}\text { "You will increasingly lose control over your } \\
\text { life, and it will be governed by the decisions } \\
\text { of outsiders." }\end{array}$ \\
\hline
\end{tabular}

\section{(2) Goals Talk}

A "goal" is a known or presumed commercial or personal interest of all or some of the parties to the negotiation. Skilful negotiators are adept at switching between "rights" talk and "goals" talk. Business people seem to be more comfortable with (and more persuaded by) goals and risks talk. These concepts reflect their training and expertise, and they do not lose control to the insider knowledge and jargon attached to discussions of legal rights.

Skilful negotiators also seem to be comfortable switching language back and forth between personal and commercial "goals" and "risks", according to which style appears to appeal to a particular audience. The following chart gives examples of how common goal and risk language can be swapped by skilled persuaders. 


\begin{tabular}{|c|c|}
\hline Goal & Risk \\
\hline 1. To settle this dispute soon & $\leftrightarrow \begin{array}{l}\text { 1.Two years of delay before a (judicial) } \\
\text { decision }\end{array}$ \\
\hline 2. To keep control & $\longleftrightarrow 2$.The lottery of a judicial decision \\
\hline 3. To avoid an awkward precedent & $\leftrightarrow \begin{array}{c}\text { 3.A judge creates an awkward } \\
\text { precedent }\end{array}$ \\
\hline 4. To avoid "floodgate of claims" & $\leftrightarrow$ 4.Floodgate opens \\
\hline $\begin{array}{l}\text { 5. To sustain good business and } \\
\text { personal relationships }\end{array}$ & $\leftrightarrow \quad \begin{array}{c}\text { 5.Required blame and counter-blame } \\
\text { language will cause alienation }\end{array}$ \\
\hline $\begin{array}{l}\text { 6. To spend time on productive } \\
\text { business activities }\end{array}$ & $\leftrightarrow$ 6.Time diverted to manage litigation \\
\hline 7. To stop paying lawyers & $\leftrightarrow \begin{array}{c}\text { 7.To pay lawyers and experts between } \\
\text { X-Y thousand dollars }\end{array}$ \\
\hline 8. To create good publicity & $\longleftrightarrow$ 8.Creation of bad publicity \\
\hline $\begin{array}{l}\text { 9. To keep decision-making in } \\
\text { hands of industry experts }\end{array}$ & $\longleftrightarrow \begin{array}{l}\text { 9. Decisions made by judges who have } \\
\text { no understanding of the industry (or } \\
\text { family, or culture) }\end{array}$ \\
\hline $\begin{array}{l}\text { 10. To avoid relatives and business } \\
\text { associates ("third parties") } \\
\text { becoming inconvenienced by the } \\
\text { conflict }\end{array}$ & $\leftrightarrow \begin{array}{l}\text { 10. Third parties and their documents } \\
\text { are subpoenaed }\end{array}$ \\
\hline $\begin{array}{l}\text { 11. To act consistently with my own } \\
\text { articulated principles }\end{array}$ & $\begin{array}{l}\text { 11. To be labelled "stupid" or an } \\
\text { "hypocrite" for failing to act } \\
\text { consistently with my declared love of } \\
\text { efficiency, control, planning, } \\
\text { generosity, etc. }\end{array}$ \\
\hline $\begin{array}{l}\text { 12. To create distance or separateness } \\
\text { between you and me/them and us. }\end{array}$ & $\leftrightarrow \begin{array}{l}\text { 12. To live/work together in } \\
\text { exhausting conflict. }\end{array}$ \\
\hline 13. To stay healthy. & $\leftrightarrow 13$. Ongoing stress will cause illness. \\
\hline
\end{tabular}

Many negotiations reach settlement because respective goals are repetitively clarified and quantified by the moderates and diplomats in each team. 
Ironically, it is an ongoing challenge to persuade negotiators to prepare a written goal/risk analysis. ${ }^{15}$

If prepared by a counterpart negotiator, such analysis is regularly devalued. A mediator may have more credibility if (s)he supervises the creation of such specific goal and risk lists. Some negotiators and mediators use generic risk-lists expressed in judicial language, which is more comfortable and authoritative for legally-trained team members. For example:

"...it is often impossible to predict the outcome of litigation with a high degree of confidence. Disagreements on the law occur even in the High Court. An apparently strong case can be lost if evidence is not accepted, and it is often difficult to forecast how a witness will act in the witness-box. Many steps in the curial process involve value judgments, discretionary decisions and other subjective determinations which are inherently unpredictable. Even wellorganized, efficient courts cannot routinely produce quick decisions, and appeals further delay finality. Factors personal to a client and any inequality between the client and other parties to the dispute are also potentially material. Litigation is highly stressful for most people and notoriously expensive. An obligation on a litigant to pay the costs of another party in addition to his or her own costs can be financially ruinous. Further, time spent by parties and witnesses in connection with litigation cannot be devoted to other, productive activities. Consideration of a range of competing factors such as these can reasonably lead rational people to different conclusions concerning the best course to follow. ${ }^{16,}$

\section{(3) Power Talk}

"Power" can be described as the actual or perceived ability to influence the emotions, beliefs and behaviours of another person. Although actual or perceived power as a persuasive force often overlaps with rights and goal/risk talk, it is again important to consider examples of "power" as separate categories of persuasion. There are two important features of power as a potential persuasive force - first, power is multilayered and has many forms; secondly, power shifts with time and circumstance. For example, a person who threatens to use publicity may be strongest before the actual disclosure to the media. Thereafter, (s)he may have no more cards to play. A nation may be strongest when threatening invasion; once the invasion occurs, the invaded may gain new forms of power such as victimhood, nothing to lose, and convenient human targets.

Some people assert that a discussion of power is somehow ignoble, unethical and/or illegal. No doubt that is true in some circumstances. Threats of violence or market isolation may amount to assault and extortion. Nevertheless complex layers of power are normally present as bargaining chips in all negotiations. For smart negotiators they

15 See J.H. Wade, "Systematic Risk Analysis for Negotiators and Litigators: How to Help Clients Make Better Decisions" (2001) 13 Bond LR 462.

16 Fitzgerald JA in Studer v Boettcher [2000] NSWCA 263 at [63]. 
are key persuaders. The naive, the wilfully deluded and those captured by "rights" talk ignore shifting layers of power. ${ }^{17}$

Set out below is another chart illustrating the multi-layers and many shifting forms of power which are used subtlety or bluntly during negotiations.

17 See Appendix A for four examples of shifting power during negotiations - the powerless "somehow" became powerful due to unexpected events and the passage of time. 


\section{Perceived and Actual Sources of Power in Mediation/Negotiation/Litigation and Life}

\begin{tabular}{|c|c|}
\hline Type of Power & Example \\
\hline 1. Experience and insider knowledge & $\begin{array}{l}\text { "I negotiate every day; I know the tricks; } \\
\text { and I know how things are done in this } \\
\text { industry" }\end{array}$ \\
\hline 2. Persistence & "I will wear you out" \\
\hline 3. Emotional & $\begin{array}{l}\text { "You are depressed and easily rattled: I am } \\
\text { calm" }\end{array}$ \\
\hline 4. Risk-taking & $\begin{array}{l}\text { "I am willing to take chances - with } \\
\text { litigation, or finding an alternative supplier" }\end{array}$ \\
\hline 5. Status-quo & $\begin{array}{l}\text { "I have the status quo (possession of the } \\
\text { business, children, job, mine); you have the } \\
\text { burden of changing that status quo" }\end{array}$ \\
\hline 6. Scorched earth & $\begin{array}{l}\text { "I don't care what happens; you can't hurt } \\
\text { me; I have nothing to lose; my fall-back } \\
\text { position is to burn everything" }\end{array}$ \\
\hline 7. Information & $\begin{array}{l}\text { "I have vital information about... (bank } \\
\text { accounts; manufacturing process; customer } \\
\text { lists; judicial hobbyhorses etc) - you don't" }\end{array}$ \\
\hline 8. Expert & $\begin{array}{l}\text { "My experts have more credibility; more } \\
\text { experience in answering difficult } \\
\text { questions...etc. than yours" }\end{array}$ \\
\hline 9. Persuasion & $\begin{array}{l}\text { "I am more articulate, charismatic, polite, } \\
\text { multi-lingual, charming... than you" }\end{array}$ \\
\hline 10. Resource & $\begin{array}{l}\text { "I have more expensive, faithful and } \\
\text { aggressive lawyers/friends/valuers/ } \\
\text { psychologists. I can spend more time and } \\
\text { money on the dispute. I will drown you in } \\
\text { paper." }\end{array}$ \\
\hline 11. Rights & $\begin{array}{l}\text { "The 'law', company policy, patterns of } \\
\text { precedent, common behaviours of decision- } \\
\text { makers, give me a stronger fall-back } \\
\text { position" }\end{array}$ \\
\hline 12. Attractiveness & $\begin{array}{l}\text { "My negotiators are attractive, well-dressed } \\
\text { and credible than yours" }\end{array}$ \\
\hline 13. Violence & $\begin{array}{l}\text { "We know where you and your friends live; } \\
\text { I cannot restrain my over-zealous relatives" }\end{array}$ \\
\hline
\end{tabular}




\begin{tabular}{|c|c|}
\hline Type of Power & Example \\
\hline 14. Structural & $\begin{array}{l}\text { "This dispute will be decided or enforced in } \\
\mathrm{X} \text { jurisdiction where the bosses/judges are } \\
\text { accessible/cheap/honest/vigilant/independent } \\
\text { or vice versa." }\end{array}$ \\
\hline 15. Confidence & $\begin{array}{l}\text { "I am confident and nothing you say can } \\
\text { sway me." }\end{array}$ \\
\hline 16. Humiliation & $\begin{array}{l}\text { "I have the moral high ground and the } \\
\text { approval of our cultural peers. You will be } \\
\text { ridiculed." }\end{array}$ \\
\hline 17. Wild irrationality & $\begin{array}{l}\text { "I (or my client) am angry, stupid and } \\
\text { depressed: reason will not touch me." } \\
\text { (variant of good cop-bad cop routine) }\end{array}$ \\
\hline 18. Time rich & $\begin{array}{l}\text { "I have nothing else to do, but to continue } \\
\text { this dispute for the rest of my/your life. You } \\
\text { do." }\end{array}$ \\
\hline 19. Preparation & $\begin{array}{l}\text { "I am organised, logical, equipped with } \\
\text { graphs and summaries. You are a } \\
\text { disorganised babbler." }\end{array}$ \\
\hline 20. Detail & $\begin{array}{l}\text { "I am a detail person; you speak in vague } \\
\text { generalities and with vague memory." }\end{array}$ \\
\hline 21. Association & $\begin{array}{l}\text { "I have powerful allies/tribes (with whom } \\
\text { you will have to trade)." }\end{array}$ \\
\hline 22. Publicity & $\begin{array}{l}\text { "You fear publicity; I love any kind of } \\
\text { publicity." }\end{array}$ \\
\hline 23. Skeletons-in-closets & $\begin{array}{l}\text { "I will not tell them, but what if the police, } \\
\text { customs, tax office, your spouse, social } \\
\text { security etc. find out about X." }\end{array}$ \\
\hline 24. Alternative fall-back & $\begin{array}{l}\text { "If you do not agree, then I have several } \\
\text { alternative (suppliers, subcontractors)." }\end{array}$ \\
\hline 25. Future relationship & $\begin{array}{l}\text { "If you are helpful now, I will be } \\
\text { considerate, polite, generous in future } \\
\text { dealings. If not...(vice versa)" }\end{array}$ \\
\hline 26. Reciprocity & $\begin{array}{l}\text { "You owe me, look at what I have already } \\
\text { done for you." "I gave up my career, now it } \\
\text { is your turn." }\end{array}$ \\
\hline
\end{tabular}

This anecdotal reflection undoubtedly reflects the narrow context of the writer's profession as a mediator predominantly in high conflict, lawyer involved mediations and negotiations in the shadow of the legal system. 
The writer has observed that, if presented diplomatically by and to the "right" team members at the time when the hearers have ears to hear, (important preconditions!), "power" propositions 6, 23, 24 and 25 are most persuasive - that is, scorched earth, skeletons-in-closets, alternative fall-back and future relationship. I have seen frequent mutual disasters when these powerful levers have been perceived as bluffs, or spoken with cathartic and inflammatory clumsiness, at the wrong time.

While standard rituals of rights, power and goals talk are occurring, it is not clear what is being communicated. The standard messages being sent, are not necessarily being heard. There is a lot of "noise" and blah-blah.

What are the purposes of this noise? Perhaps it is habit; or a hangover from barristerial advocacy; or nervous chatter; or a hired mouth attempting to justify fees; or a naïve hope that something in the shotgun of blather may stick; or be ubiquitous good cop - bad cop routine; or insightful knowledge that repetition is the essence of learning.

\section{Cialdini's Sales Levers}

Other writers create overlapping but some different categories of persuasion apart from the rights, goals (risks), and power categories set out above. For example, in the important book by Robert Cialdini, Influence - Science and Practice, ${ }^{18}$ Cialdini identifies the six most effective persuasive "levers" in the areas of national and international sales. They are:

1. The Consistency Principle

2. The Authority Principle

3. The Reciprocity Principle

4. The Similarity Principle

5. The Scarcity and (converse) Nothing-to-Lose-Principle

6. The Coalition Principle

Principles 1, 3 and 4 could be classified as forms of "moral" persuasion. These principles reflect in startling fashion what every computer and car salesperson is doing to you.

The writer has found Cialdini's insights to be very helpful as a mediator trying to set up negotiation meetings, and reframe client's goals and risks. In appendix B are some illustrations of practical applications of these concepts.

\section{Persuasion and Pause}

One of the standard responses to the doubt creation dance is adjournment or pause. Where there is predictable resistance to a preferred negotiated outcome, one or more of the disappointed parties declares:

- "I will get further instructions from my clients."

- "We are getting nowhere; this is a waste of time."

- "We cannot make a decision until we have more clarity about ..." (the value of a business, cash flow, what a witness will say etc)

18 R B Cialdini, Influence-Science and Practice $4^{\text {th }}$ ed, 2001 
The motives for adjournment are many - laziness, disorganisation, fear of regrets, fear of armchair antics, need for more "facts"; confusion or ambush due to new information received; need to "sign up" one's own client for self protection; attractive status quo to retreat to during adjournment; hope that adjournment will escalate pressure; deep grief at emerging less-than-hoped-for agreement; hope against hope that "something will change" during the pause etc.

This catalogue of possible motives may help to explain why adjournment and procrastination are such popular and predictable responses to allegedly persuasive "doubt creation". That is also why some lawyers (and auctioneers) are unwilling to "sink costs" into a series of negotiation meetings, as a discontented party can so readily escape pressure by adjournment. Better to wait until the door of the court (or auction?) when all escape routes are closed - cut a deal or risk some "losses" immediately before a judge (most judges will punish last minute attempts to adjourn).

That is, routine "persuasion" becomes more effective as easy fall-back options such as adjournment diminish.

\section{(Conscious) Deception of Others in Negotiation and its Shifting Boundaries}

Attempts to create doubt via rights, goals and power talk between parties are often muted by mutual suspicion and deception. Anecdote and research ${ }^{19}$ show clearly that negotiators, including the majority of lawyers, standardly lie - "This is my bottom line"; "This is my best offer"; "This is a reasonable offer"; "If you don't accept this offer, I have advised my client to go to court"; "My client is entitled to 60\%"; "A judge would never accept that argument" etc; or make negligent statements - "the accounts support what I'm saying"; "there are no more relevant documents"; "my client is scrupulously honest" etc.

Accordingly, comments which should theoretically create doubt and be persuasive to some extent, are frequently ignored in the babble or perception of deception. ${ }^{20}$

Such inconvenient truths often lead to the response that these orthodox negotiation lies are "merely" harmless ritualistic puffery.

It is arguable that these intentionally or negligently false statements are both illegal for all negotiators in Australia ${ }^{21}$ and unethical for lawyers ${ }^{22}$ despite being common.

19 R Davis, "Negotiating Personal Injury Cases: A Survey of the Attitudes and Beliefs of Personal Injury Lawyers" (1994) 68 Aust. L J 734.

20 See Appendix $\mathrm{C}$ for examples of standard deceptive illegal and unethical behaviours which recur during negotiations.

21 eg W. Pengilley, "When Silence in Negotiations is Misleading" (2005) July NSW Law Soc J 57; "The Vendor, The Agent, the Independent Adviser \& Misleading Conduct", (2006) April NSW Law Soc J 52; "But You Can't Do That Anymore - The Effect of Section 52 on Common Negotiation Techniques" (1993) 1 Trade Practices Law J 113.

22 R. Lewicki et al, Negotiation (2006), Ch 16; Legal Services Commissioner v Mullins http:www.lsc.qld.gov.au/documents/MullinsLPT06-012.pdf. (In 2006, barrister held to be acting unethically by remaining silent about his client's terminal cancer during negotiations for personal injury payout). Hear also radio commentary on this case at http://www.abc.net.au/rn/lawreport/stories/2007/1934886.htm 


\title{
Self-Deception - An Underlying Theme
}

The previous framework and analysis of this paper implies that we as human negotiators are a rational and organised species, carefully articulating and weighing lists of visible rights, goals and power. This may be true sometimes. More frequently we appear to be the victims (or beneficiaries) of our own self delusions and tricks of mind and emotion. The errors of confidence abound.

Psychological studies give many helpful insights into the process of human decisionmaking, and how we are all prone to error. These tendencies to err are sometimes collected under the labels of "cognitive heuristics", or "decision-making shortcuts" or more simply, "decision traps". Life is so complex, we all have inbuilt shortcuts to manage this complexity.

Most of these decision traps profoundly influence negotiation decisions. In other words, all the parties to the "decision-making" of negotiation, including a mediator, are prone to delusion and self-deception. This is particularly challenging, as the opposition is trying to deceive me, and at the same time I am already self-deceived! Deception, delusion and double-talk abound. How am I supposed to make a wise decision?

Again, when and how should a mediator, or a team moderate, educate himself/herself/the parties/their tribal members, about these lurking decision-making demons?

The stereotype of the persuasive negotiator set out at the beginning of this paper, usually has not studied psychology. However, the school of hard knocks has taught him/her about the constant fallibility of human decision-making. This wisdom is then reflected in the ubiquitous phrases:

- "On my understanding."

- Correct me if I'm wrong..."

- "Am I missing something..."

- "Only fools rush in..."

- What assumptions are we making here?"

- "I've been wrong many times before, so..."

- "On what evidence do you base that statement..."

Set out below are examples of some of the decision traps which we have all seen at work in our own lives, and in daily, national and international negotiations.

\section{DECISION- MAKING SHORTCUTS AND TRAPS (FOR NEGOTIATORS AND OTHERS) ${ }^{23}$}

\author{
The ANCHORING TRAP: Over-relying on First Thoughts
}

The SUNK-COST TRAP (ENTRAPMENT):Protecting Earlier Choices

\footnotetext{
${ }^{23}$ See Lewicki (2003), note 1; Hammond note 2; Fine note 9.
} 
Mythical FIXED -PIE Beliefs

The STATUS-QUO TRAP: Keeping on keeping on

The CONFIRMING EVIDENCE TRAP: Seeing what you want to see

The FRAMING TRAP: Triggering a premature answer with the Wrong Question

EASILY AVAILABLE INFORMATION TRAP: "What an impressive chart!"

The WINNER'S CURSE: "Perhaps we could have done better?"

The OVER CONFIDENCE TRAP: Being too sure of your knowledge and ability

The BASE-RATE TRAP (The Law of Small Numbers): Neglecting Relevant Information ("The statistics clearly show ...")

- SELF-SERVING BIAS: Environment versus Personality ("I am under a lot of pressure; you are just disorganised")

* IGNORING OTHERS' INTERESTS AND PERCEPTIONS: "Let's Get Down to Business"

REACTIVE DEVALUATION: Ridiculing “Opposition's” Ideas and Behaviour 


\section{DECISION - TRAPS: EXAMPLES}

You will hear younger and older lawyers make the following comments. Identify which decision-making trap the speaker has probably fallen into for himself/herself and for his/her client. Remember from Lewicki and Hammond that these traps have been "proven" repetitively to be part of the unconscious decision making process of lawyers and other professionals. The myth of rationality inculcated at law schools is indeed a myth.

1. "They want to talk about possible future business. What a waste of time. This dispute is just about money".

2. "Their behaviour is outrageous. They deserve to lose".

3. "This is a cut and dried case". We will walk all over them in court".

4. "My client has been under a lot pressure at work. Imposing deadlines on him is quite unreasonable".

5. "We have spent over $\$ 20,000$ in legal costs, and a year of negotiation. We are not giving in now".

6. "They want $\$ 600,000$. We will never be able to settle this".

7. "They have given us a clear summary of the value of the business assets, and how their profits dropped after the accident".

8. "Our law firm has a fabulous record, over $80 \%$ of wins, in any litigation we undertake".

9. "It's time to stop talking and get down to the bottom lines here".

10. "I worked hard for my client, I got a good outcome in the terms of the lease; and now she's ungrateful".

11. "Their client wants to increase the payments to us; spread them over five years; and secure the payments on his business. That would never work".

12. "If we keep wearing them down with paper, they will give in before the court hearing".

13. "I told you that they are not to be trusted - they did not answer my letter; arrived late for the meeting; and now sit outside talking and snickering obviously unprepared".

14. "We handle hundreds of these cases. We know what we are doing".

15. "From my experiences in court, judges do not like emotional witnesses".

16. "Big banks which hire large law firms rarely lose in court. They are too powerful. Just look at the cases over the last 10 years". 


\section{Procedural and Emotional Awareness and Skills}

The stereotype excellent negotiator described at the beginning of the paper has a number of other micro behaviours which relate to procedure and emotions for all parties involved.

When a negotiator talks, or writes about perceived substantive rights, goals and power, this occurs amidst behaviour and language relating to procedure and emotions.

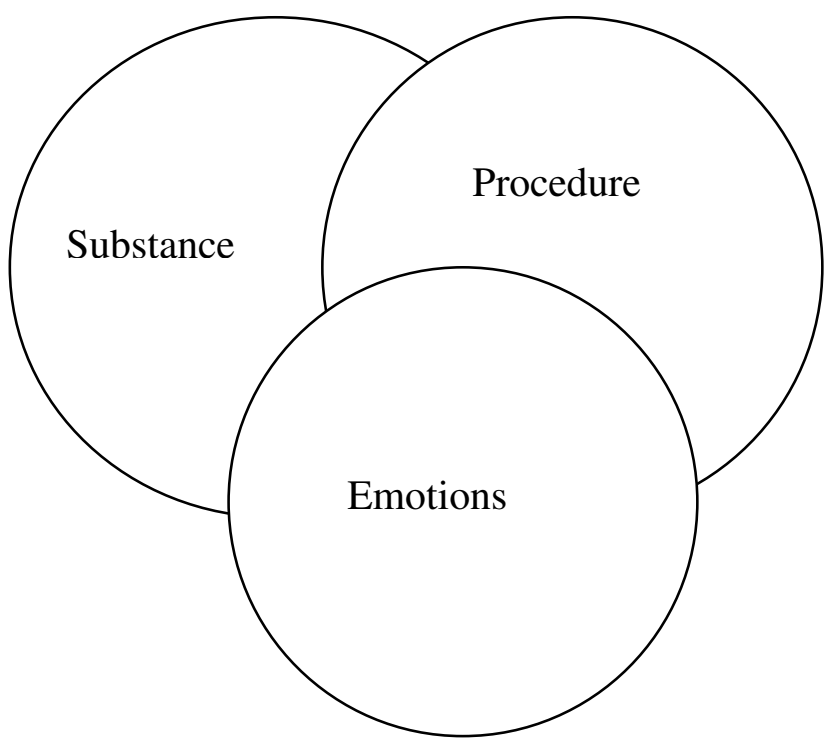

This behaviour, or the absence thereof, relating to "intangibles", has a profoundly persuasive effect on the majority of negotiators. Of course, it is possible only to give a few conceptual and linguistic illustrations of such a vast topic. Again, it is important to emphasise that each of these illustrations vary in effect from one culture to another.

These illustrated behaviours provide the persuasive context in which the substantive messages are wrapped.

Listening respectfully: "uh-huh"; "yes"; "please continue"; nodding; appropriate eye contact.

Acknowledging emotion: "I can see that you felt 'strongly'; 'frustrated'; 'angry'; 'disappointed'; 'concerned' etc.

Reframing: "The only solution you can see at present is creating distance between you"; "You lost some respect for each other"; "You are hoping for a big financial payout"; "You have had many differences in the past" etc.

Summarising: "Have I understood correctly, there are three reasons...?". "So you believe we have four major risks..."; "So you are suggesting that that figure is justified by five arguments"; etc.

Questions: Especially - 
1. Open questions - "Can you elaborate upon that?"; "Could you tell me more about ...?"

2. Checking questions - "Am I correct?" "Have I understood you correctly?"; "Are we on the same page?"

3. Hypothetical questions - "What if you have to be neighbours for several years?"; "Assuming that we are able to pay that amount, what security...?"; "If we increased your salary, what would we receive in exchange?"

4. Probing questions - "Is that inconsistent with what you stated previously?"; "How do you reconcile those bank statements...?"; "Why do four other witnesses say the opposite?"; "How does that solution fit with the mission statement of your company?" etc

\section{Procedural awareness}

A persuasive negotiator often appears to "rise above" the immediate substantive and emotional discussions occurring in person or by mail, and open a reflective discussion about procedure. This procedural awareness, or role as a quasi-mediator, is attractive as negotiators often experience intense frustration and "loss" - "we are going nowhere"; "we have been over this before"; "she is a broken record"; "tell us something new"; "this is another dead end"; "they are just stonewalling us"; "I told you that this would be a waste of time" etc.

The procedural freak rises above the fray either preventively or reactively with an array of standard colloquial pauses, expressed via bumbling Columbo or articulate diplomat.

- "I was wondering, it would be helpful to me if..."

- "I am lost; could we try to answer..."

- "I know that I'm a bit slow, but could you summarise that for me again Bill".

- "Before we look at our differences, could I suggest that we have some things in common"

- "How would you like to run the meeting today? Can I suggest some steps which have been helpful, at least to me, in the past?"

- "We have been on that topic for 15 minutes (or 15 emails) - could we leave it for the moment, and come back to it later?"

- "Can I ask a question?"

- "Could Mary and I write up an agenda during the tea break?"

- "If you threaten my client, what do you expect him to do? Would it be predictable for him to respond in kind?"

- "We have been swapping threats for a while; could we now brainstorm some solutions and we can return to the threats later."

- "Could the accountants jointly address us on that topic for say 15 minutes so that we can understand why they are so far apart?"

- "Would you be prepared to ask a small sub-committee to list the options and recommend their top choice?"

- "Can you suggest to me David, how I could sell that offer to my client and her constituents? I know it is late, but at the moment I cannot think of one persuasive reason."

- "I don't know about you, but I need some coffee..." 
- "I will not even mention that offer to my client; it is petrol on the fire."

- "Is there any way we can avoid the usual routine of extreme offers, and then months of chipping away at each other? As a lawyer, I need a new tennis court, but our clients may have better things to do with their money."

It is easy to acknowledge the importance of concepts such as procedural skill and emotional awareness. However, this is like reading a book about golf. There remains years of supervised practice before these "persuasive" concepts are reflected in a repertoire of language and negotiation "instincts" while negotiating under pressure.

\section{Conclusion?}

The anecdotal and more systematic study of persuasion methods used in negotiation is both helpful and daunting.

It is helpful to know what range of tactics and language to practise, and what is probably being attempted by your counterparts. "Competence" is demystified to some extent.

However, this study is also daunting. There are so many unknown variables in the persuasion soup, and diagnostically it is a challenge to use even the known and practised persuasive methods at the "right" time, in the right quantities, tone and context. This is not a counsel of despair. There is a small number of excellent negotiators around at your office, or home, ready to be analysed and copied. 


\section{APPENDIX A}

\section{POWER EXERCISES}

The unpredictable loss of power by the apparently "powerful".

The passing of time may complicate GOALS, RIGHTS and POWER.

1. An elderly Italian couple were defending a claim by their daughter to a share of their 5 acre properly on which she had built a business. They stonewalled her law suit and requests for a share of their property. They were rich, determined, with nothing else to do but fight, and were culturally outraged at their daughter's lack of respect.

Suddenly, they accepted a written offer which gave the daughter a substantial portion of what she wanted. Why?

2. A wife accepted an offer of a $\$ 2$ million payout in a matrimonial property dispute. Two mornings later, she went to her lawyer and changed her mind.

The lawyer was nervous that she would complain to the Law Society about being "coerced" into a settlement, so he agreed to argue her case for more money. He doubted her success, as \$2 million was in the range, she had willingly signed a settlement, and was represented by a lawyer.

One year later, at the door of the court, the husband's expert valuer was suddenly disqualified from giving evidence as it emerged that he once had owned shares in a company owned by the husband.

Rather than wait another 10 months for a new valuer and trial date, the husband agreed to pay her an extra $\$ 500,000$. Why?

3. At a mediation about the division of $\$ 14.5$ million, the lawyers for a husband and wife agreed publicly that the range of awards which a judge might make to this wife was between 20\%-33\%\$. The husband's first offer was 19\%; and the wife claimed $40 \%$ (ie an "insult" offer). The husband then bid against himself $19 \%-25 \%-30 \%-32 \%$. Why?

4. A cane farmer was awarded $52 \%$ payout from his cane farm; and his wife $48 \%$ (and actual ownership of the heavily mortgaged cane farm) by a trial judge. However the trial judge made a mathematical error when calculating the wages due to their son, who had worked on the farm, being approximately $\$ 500,000$.

The parties came to mediation to recalculate the son's correct wages. However, the husband said he now wanted $57 \%$ of the assets, paying zero wages to his despised son. His lawyers said that he had no "rights" to 57\%, and that a court would confirm the 52:48 split, with an amount for wages "off the top" for his son. The farmer ignored his own lawyers, and stonewalled.

His wife and son eventually agreed to take 57:43 and zero wages. Why negotiate such an "unjust" result? 


\section{APPENDIX B}

\section{CIALDINI'S METHODS OF PERSUASION IN BUYER-SELLER NEGOTIATION}

Set out below are a number of principles which have been observed in use when people are attempting to persuade others during the course of sales negotiation. ${ }^{24}$

1. Consistency Principle

2. Authority Principle

3. Reciprocity Principle

4. Similarity Principle

5. Scarcity and Nothing-To-Lose Principle

6. Coalition Principle

All of these were established to some extent by repeated research projects in various cultures.

All of these principles have exceptions; and can be over-used or under-used.

\section{CONSISTENCY PRINCIPLE}

Most people like to act consistently with principles they agree with; or like to rationalise consistency between their own beliefs and behaviours.

\section{Consequences:}

(a) Encourage others to talk

(b) Listen constantly

(c) Ask questions regularly: "Why is that unacceptable to you at present?"; "Why are they saying 'no'?".

(d) Extract and summarise principles which are important to others

(e) Frame agenda in line with others' principles

(f) Search for common principles held by both or all parties

(g) Once other's principle or values are identified, this enables the comment "just as $\mathrm{X}$ is important to you, so for us .....".

(h) Enables swaps, eg "what if I help you with what is important to you ...".

\footnotetext{
${ }^{24}$ Try to add illustrations, applications and modifications of these principles from your own life or from examples in the media.
} 


\section{AUTHORITY PRINCIPLE}

People tend to be persuaded by authority figures who are (i) trustworthy; and (ii) expert, in a particular field.

\section{Consequences:}

(a) Find a trustworthy expert to present at negotiations; or write an opinion based on everyone's facts.

(b) Get written opinions from several such experts.

(c) Use an expert evaluative mediator.

(d) "I have been practising in this field for 30 years and in my experience ...."

(e) Try to gather statistics on what is 'common practice', or data from independent consumer reports.

(f) Use an expert as a go-between.

\section{RECIPROCITY PRINCIPLE}

" ... we owe others certain things because of what they have previously done for [or to] us ..."

\section{Consequences:}

(a) Spend (a long) time developing relationships before 'beginning' actual negotiation.

(b) Exchange gifts.

(c) Make a generous or modest concession and expect the same in exchange.

(d) Bring wine and glasses to the negotiation table.

(e) Only negotiate with friends.

(f) Only negotiate against a team which contains at least one school or professional colleague (eg French city business culture).

(g) foreshadow a series of small concessions matched by a series of small responses (eg Nuclear disarmament).

(h) Mirror effect, "If you want politeness, be polite; if you want aggression, be aggressive".

(i) Create doubt, "How do you expect them to respond, if you behave in that way?".

(j) Make it overtly or subtly clear that you know people who are 'connected to' the opposition (eg, "How is your Uncle Fred? We play golf together.") etc.

(k) People who work together regularly (eg lawyers at the door of the court; employers and union officials; builders and subcontractors) will tend to reach agreement as each will need the good will of the other on hundreds of occasions in the future. Nevertheless, they may engage in theatrical aggression for the sake of constituents, so try not to overreact except theatrically.

(1) Be reliable and trustworthy.

(m)When you believe that others are behaving 'badly', name what they are doing and advise them of your perception. 
(n) Be careful about 'winning' negotiations in ongoing relationships (eg With children, spouses, employees). There will be (severe) paybacks.

(o) Normally, begin business or litigious negotiations 'high-soft' or 'low-soft' so that there is room to make concessions and expect concessions in exchange. Learn the code language to make it clear to others that this is a 'high-soft' or 'low-soft' offer.

\section{SIMILARITY PRINCIPLE}

We tend to feel more relaxed with, and more persuaded by, people who are similar to us in belief, appearance, profession, language, and sense of humour.

\section{Consequences:}

(a) Pick your own negotiation team members carefully.

(b) Ask a lot of questions about the style and characteristics of all possible 'opposition' members.

(c) Subtly or overtly request that certain people attend negotiations; or not attend; or be isolated in separate rooms.

(d) Try to find negotiators to 'match' influential or aggressive negotiators on the other side.

\section{SCARCITY AND NOTHING-TO-LOSE PRINCIPLE}

A person or group who has, or is perceived to have, little or nothing to lose by the 'failure' of the negotiation, is normally very powerful in negotiations (eg Wealthy bank or insurer; impoverished student; McLibel; agents such as lawyers, union representatives or armies). Conversely, if a resource is apparently scarce and is perceived to be unavailable elsewhere, sign up now.

\section{Consequences:}

(a) Always try to have acceptable alternatives to the current negotiations (eg alternative car dealers).

(b) Conversely, create monopolies!

(c) Beware of spending too much time and money negotiating with time-rich, unemployed, asset-poor, articulate martyrs ("resentniks").

(d) Try to discover intangible goals of "I have nothing to lose" negotiators (eg Need for recognition; publicity; vengeance, etc) and check this list with that apparently powerful person(s).

(e) Try to include in the negotiations tribal members who may have some influence over the powerful (eg, a union; a consumer association; a spouse; a newspaper reporter).

(f) Give the nothing-to-lose powerful negotiator something to lose (eg, to a powerful bank, the possibility of de-registration or prosecution as a monopoly; to an impoverished group of terrorists, give some jobs, houses, mortgages, status, children, etc.).

(g) Beware of people who say "I don't care"; "I can walk away"; or "You don't have any choice"; "You can't fight a bank / insurance company". They may be correct, or dangerously deluded. 


\section{COALITION PRINCIPLE}

Where a majority of people in a group come to a clear agreement, it is difficult for the minority to change that coalition's consensus.

\section{Consequences:}

(a) Prepare consensus statements / petitions by a number of key people before or during any negotiation.

(b) Brief key people to confirm the opinion of some or all negotiation team after the negotiation is over.

(c) Coach a negotiation team / tribe / organisation not to split, and/or speak through one representative, during negotiations. 


\section{APPENDIX C}

\section{COMMON “AMBIGUOUS” BEHAVIOURS IN NEGOTIATION AND LITIGOTIATION}

1. False statements which are (i) intentional, (ii) reckless (iii) negligent or (iv) innocent relating to:

Facts: "This business has gross income of at least one million per year."

Evidence: "The accounts show clearly income and expenses."

Intention: "We intend to live in Australia."

"I do not intend to set up a competing store".

Causation: "It is unlikely that the subsidence of the soil caused the cracks in the building".

"The loss of profits was not caused by management decisions."

2. Silence which is intentional, reckless, negligent or innocent about any important or "material" fact, evidence, intention or causation

a. eg Silence about:

i. The house has termites

ii. The highway may soon be diverted

iii. My expert's report suggests that I am to blame for the accident.

3. "Half-Truths" which are intentional, reckless, negligent or innocent. (A halftruth is a sentence which is literally correct, but a reasonable hearer is likely to reach a false conclusion)

a. Eg "This restaurant seats 179 people" (but only has liquor licenses for 102 people).

b. "There are no formal development applications lodged with the Council" (but there have been ten informal development applications)

c. "I have advised my client that (s)he is entitled to $\$ 1.3$ million" (on a good day in court; on a bad day (s)he may receive $\$ 120,000$ )

4. Initial Truth, then silence when facts change:

a. Eg "My business is worth $\$ 3$ million" (by the time of the signing off, it has dropped to $\$ 2.3$ million). 


\section{Puffery and Vague Platitudes}
a. "This is a reasonable offer."
b. "This is a good business."
c. "Don't miss this golden opportunity."

6. Bluffs and Threats which are intentionally or recklessly false:
a. "I have an alternative buyer awaiting."
b. "If we do not get $\$ 550,000$, we are going to Court."
c. "If you don't leave quietly, you will never work in this industry again."
d. "My client is a crusader/martyr/maniac; litigation is no problem for him/her."
e. "This is my bottom line."

7. Convey the false impression that you are in no hurry. ("Ill wait till the door of the court"; "Time is on my side")

8. Extreme Offers (ambit claims or "insult" offers).

9. Add ons

Whenever agreement is in sight, add another demand. ("There is one more thing...")

\section{Good cop/bad cop routine}

"Deal with me, otherwise you will have to deal with angry irrational X."

\section{Flattery and Ingratiation}

"I've always wanted to meet you."

"I've heard a lot about you."

"That is a helpful idea."

\section{Research and "Infiltration"}

Pay investigators to discover counterpart's goals, styles, and hidden information.

\section{A Lawyer talks directly or indirectly to the counterpart client}

“They have an obstructive lawyer; we must communicate directly with them!" 
A. Where are "ethical" lines drawn currently on each of the above common behaviours?

B. Using which of the five schools of "ethics"?

C. Where are the "legal" lines currently drawn on each of the above common behaviours? ${ }^{26}$

D. In which cultures and jurisdictions?

E. With what consequences where an ethical or legal "breach" occurs?

\section{SOURCES OF ETHICS OFTEN (NOT ALWAYS) REINFORCE EACH OTHER}

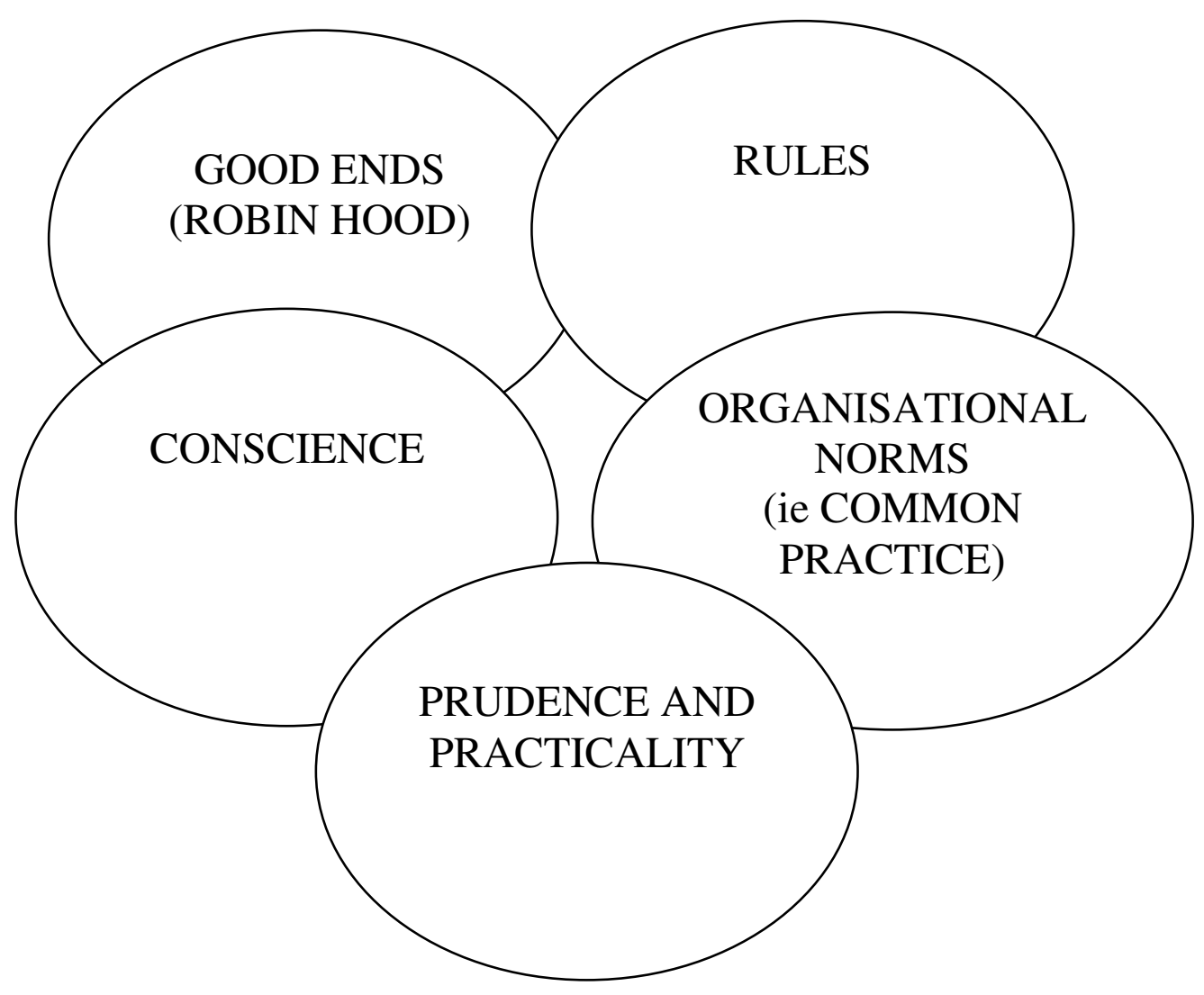

25 Lewicki at note 1, chapter 9 helpfully analyses four traditions of ethics, namely Robin Hood (the end justifies the means); rule-based (what does the Code of Ethics say?); personal ("I believe..."); and normative ("everyone is doing this"). A fifth tradition of pragmatism ("don't do this as you will get into trouble") appears to be the dominant conversation amongst lawyers.

26 See helpful summaries of legal pressures on negotiators by Korobkin, Moffit and Welsh "The Law of Bargaining" in ch. 21 of Schneider and Honeyman note 3; and Spegel, Rogers and Buckley, Negotiation - Theory and Techniques (1998) ch. 10 "The Black Letter Law of Negotiation". 